\title{
SPECIFIC ASPECTS OF THE RETROFITTING DESIGN AND SEISMIC ASSESSMENT OF A HERITAGE PEDESTRIAN BRIDGE
}

\section{SPECIFIČNI ASPEKTI PROJEKOTVANJA REHABILITACIJE I SEIZMIČKE PROCENE PEŠAČKOG MOSTA KAO GRADITELJSKO NASLEĐE}

Emil YANEV

\section{INTRODUCTION}

The River Arda's Cascade is the only system of large dams in Bulgaria created along a single river basin. In the upper course of the river, near the town of Ardino, the "Byalizvor" Hydroelectric Power Plant (HPP) is situated, which has been in operation since 1952. To provide a waterfall for the power plant a catch-water dam along the river had been constructed, consisting of a dam wall and a floodgate tower with exhaust panels.
PREGLEDNI RAD

REVIEW PAPER

UDK:625.745.11

doi:10.5937/GRMK2004065Y

\begin{abstract}
Access to the service of the gates is carried out by a pedestrian bridge consisting of two structures: a steel platform on stone pillars at the beginning of the approach from the left bank of the river and a reinforced concrete platform on the same type of pillars to the end of the approach at the floodgate tower. The reinforced concrete part of the bridge, together with the pillars, was destroyed after enormous floods in January 2016 when the river came.
\end{abstract}

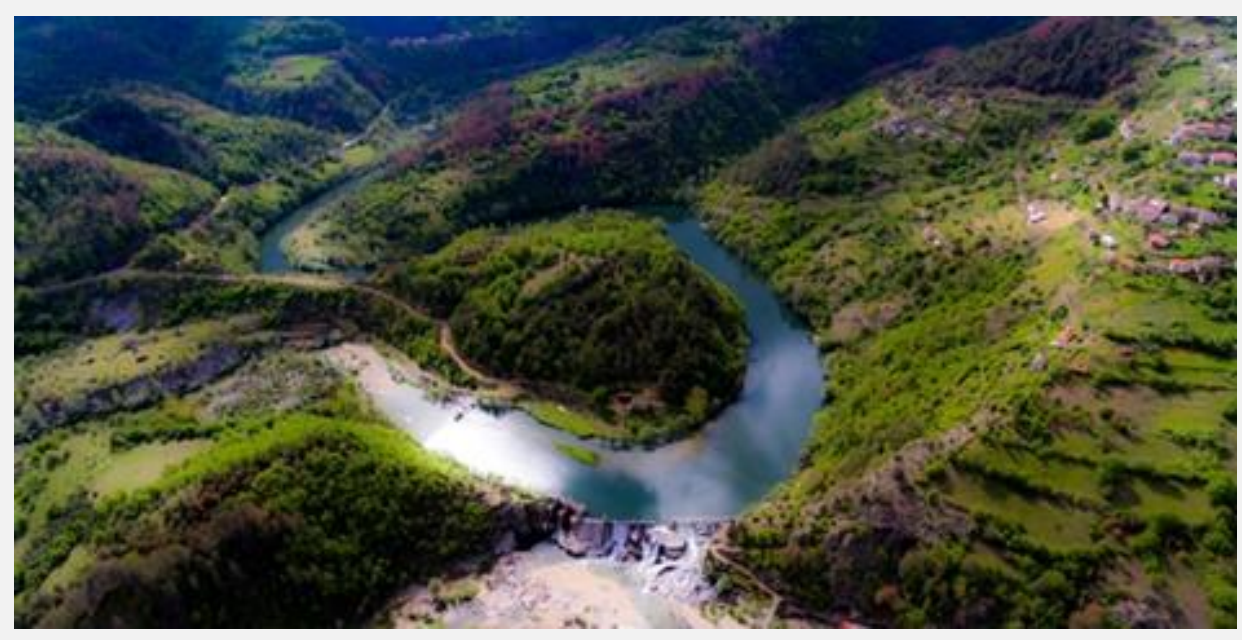

Figure 1. Plan view of the river and catch-water dam

Emil Yanev, Chief Expert, "Construction and Renewable Energy" Directorate at Risk Engineering Ltd, Sofia, Bulgaria, emil.yanev@riskeng.bg 


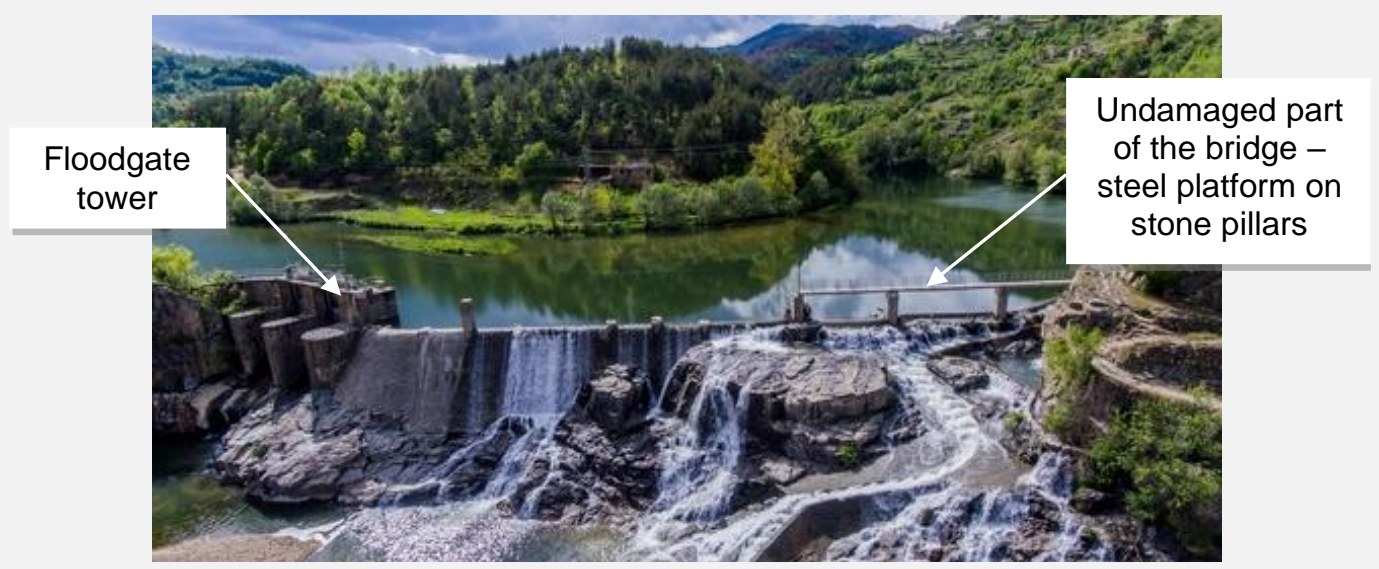

Figure 2. Existing situation after accident. The destroyed part of the pedestrian bridge

As a result a project for restoration of the related part was made with appropriate structural planning and an optimal number of supports to prevent the river from backwatering.

\section{INFORMATION RECEIVED FROM THE ASSIGNOR. FEASIBILITY STUDY}

In the original form of the bridge, the pillars in the section of the dam wall are at a light distance of $4.0 \mathrm{~m}$ and it doubles to $8.0 \mathrm{~m}$ in the last three openings. According to the original project which the Client provided to our team the existing construction of the pillars is made of stone masonry, built of cement-sand mortar, filled with a core of non-reinforced concrete. The overall dimensions of the pillars section is $100 / 140 \mathrm{~cm}$. Above the masonry part of the pillars there is a concrete hat, on which the structure of the existing steel footbridge sits. The pillars height above the dam wall edge is $3,0 \mathrm{~m}$, they enter 1.5 $m$ into the body of the dam wall without being anchored in it.

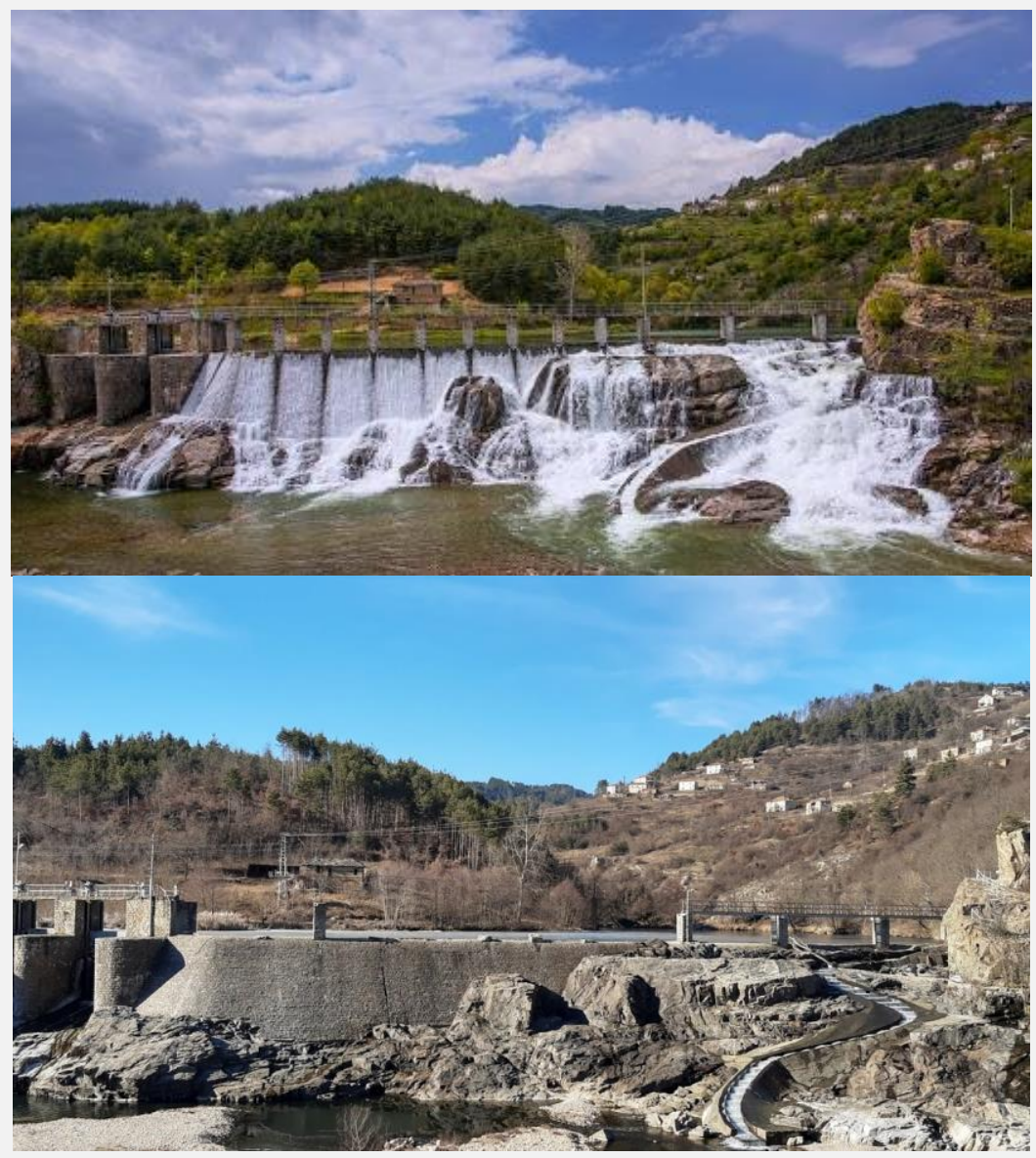

Figure 3. Comparison of the bridge in its original form (up)and now (down) 
As a result of their construction with non-reinforced concrete, the columns have insufficient bending capacity due to which under the action of horizontal loads during the flood they collapsed primarily by shear in cross section at their connection with the dam wall, as evidenced by the remains. The part with the narrower wheelbases of the pillars was mainly destroyed.

\section{BASICS OF DESIGN. STRUCTURAL CONCEPT}

\subsection{Basic requirements of the assignor. Durability adjustment}

The same levels of reliability for load-bearing capacity and serviceability are accepted according to the section 2 of EN1990.

The degree of responsibility of the facility with the accepted reliability is CC2 (Table B 1, EN1990). The significance class corresponding to the accepted degree of responsibility is class II (average significance) according to item 2 (4) P of EN 1998-2: 2006.

According to Table 2.1 of EN 1990 the construction corresponds to category S5 with a design service life of 100 years.

\subsection{Project solution}

The facility will consist of stone-lined reinforced concrete pillars, anchored in the body of the spillway wall on which is seated a top steel structure, equipped with safety railings and steel pavement. The pillars form five intermediate axes (axes 3-8) of $9.0 \mathrm{~m}$ each, identical to the original openings remaining after the accident (axes 1-3) (Figure 4). Over the pillars the steel footbridge is seated on the newly designed foundation over the existing floodgate tower on the right along the river and on a stone masonry pillar on the existing part of the footbridge along axis " 3 ". The stone masonry pillar at the connection of old and new structure will be replaced with reinforced concrete. The existing pillar near the floodgate tower falls between axes "6" and "7" of the new footbridge and will be removed.

The number of new supports is halved compared to the original solution and has been adopted so as to satisfy the passage and non-retention of solid debris. The overflow fields are larger than the existing ones, which is a prerequisite for the better operation of the overflow (the overflow front has been increased by about 5 meters), reducing the overflow height, compared to the original solution. At the same time, with the solution thus adopted, the wheelbases of the columns become commensurate, thus their response to seismic impact will be equivalent due to the regularity of the structure in plan compared to the original solution.

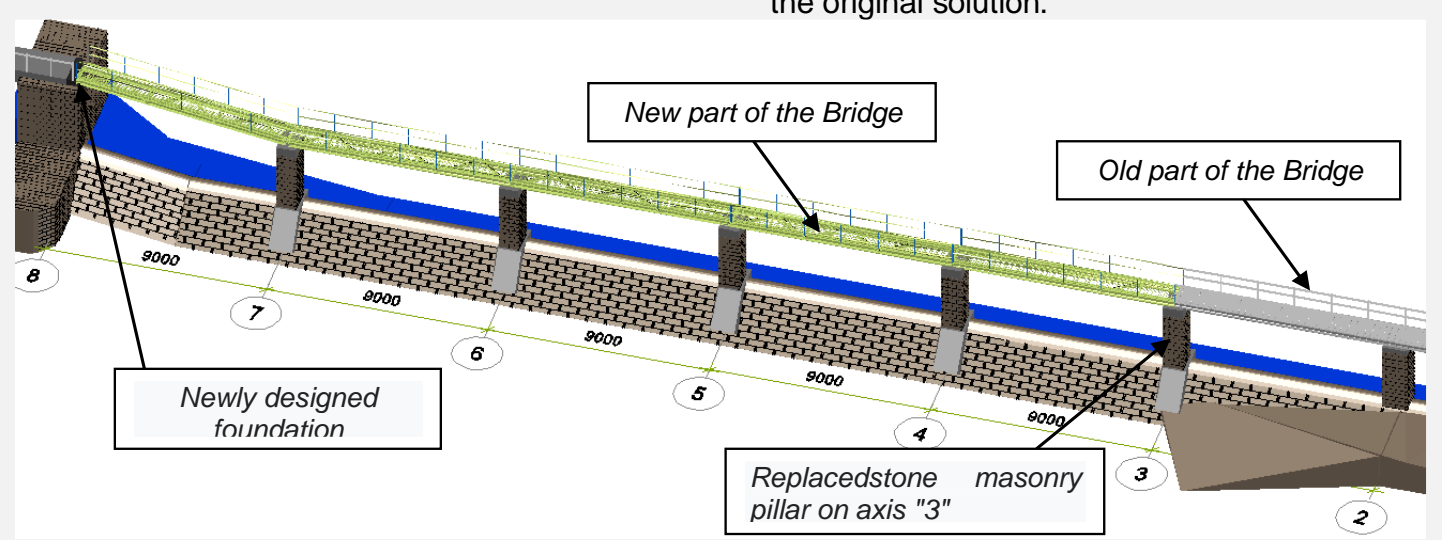

Figure 4. Structural concept. General view of the facility from axes 2-8

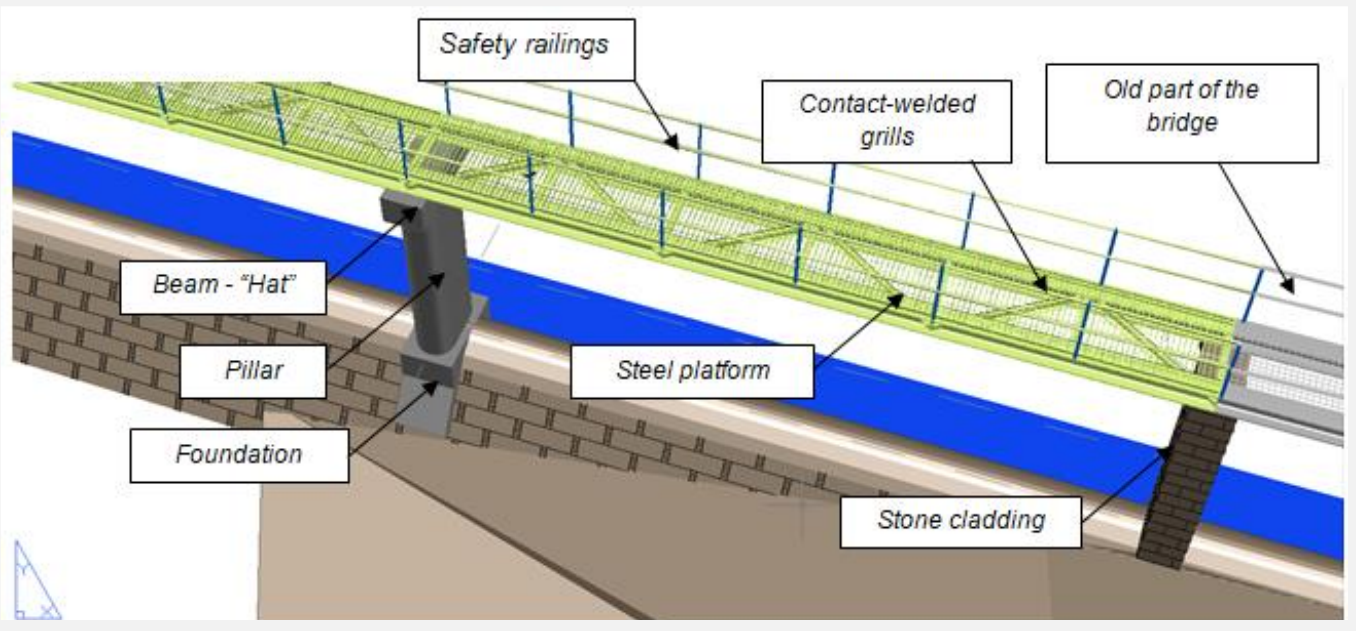

Figure 5. Project solution. Structural elements of the bridge 
In its upper part the pillars end with a crossbar (coussinet), on which, by means of supporting devices, the structure of the superstructure is seated. The body of the pillars is lined with row stone masonry of granite blocks with a thickness of $15 \mathrm{~cm}$ and a row height of $20 \mathrm{~cm}$, a multiple of the height of the rows of existing stone masonry pillars. The cladding will be performed before concreting, with pre-fixing of the stone blocks with steel fastening to the reinforcement from the body of the pillars.

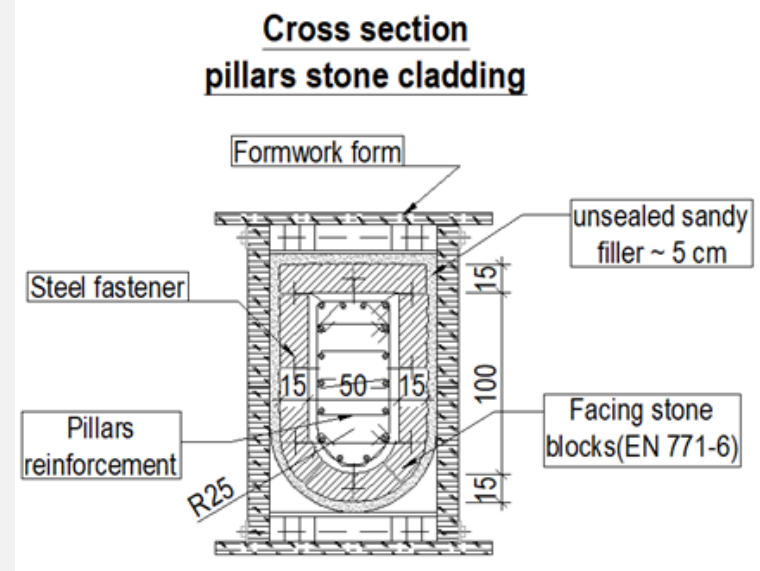

\section{Steel fastener on stone blocks cladding}

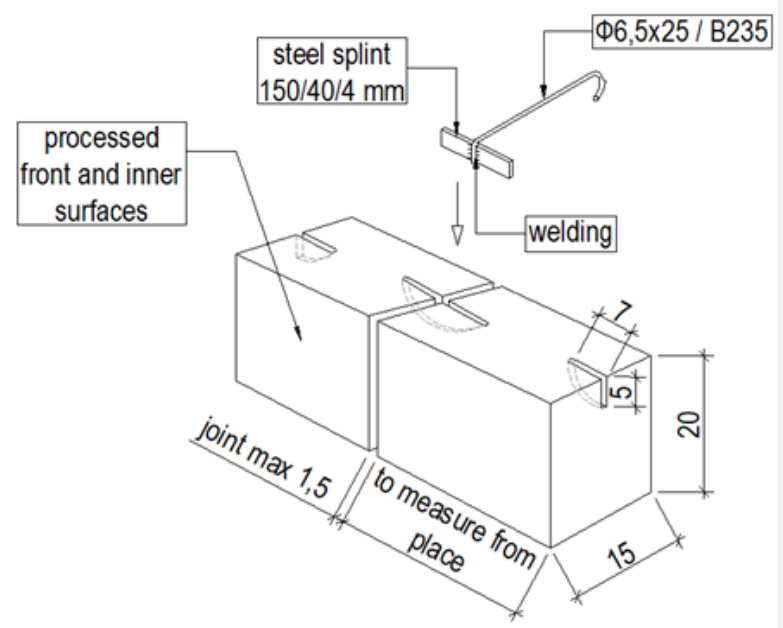

Figure 6. Stone cladding. Cross section with formwork and steel fastener on stone blocks

The foundations are anchored in the wall with injection of adhesive anchor chemical paste and reinforcing steel rods, the holes for which are drilled by pneumatic impact drilling. Additionally, in the geometry of the foundation, a front indentation has been added along the contours of the wall, which reduces the stresses in the main plane by increasing its area.

The foundations are anchored in the wall with injection of adhesive anchor chemical paste and reinforcing steel rods, the holes for which are drilled by pneumatic impact drilling. Additionally, in the geometry of the foundation, a front indentation has been added along the contours of the wall, which reduces the stresses in the main plane by increasing its area. 

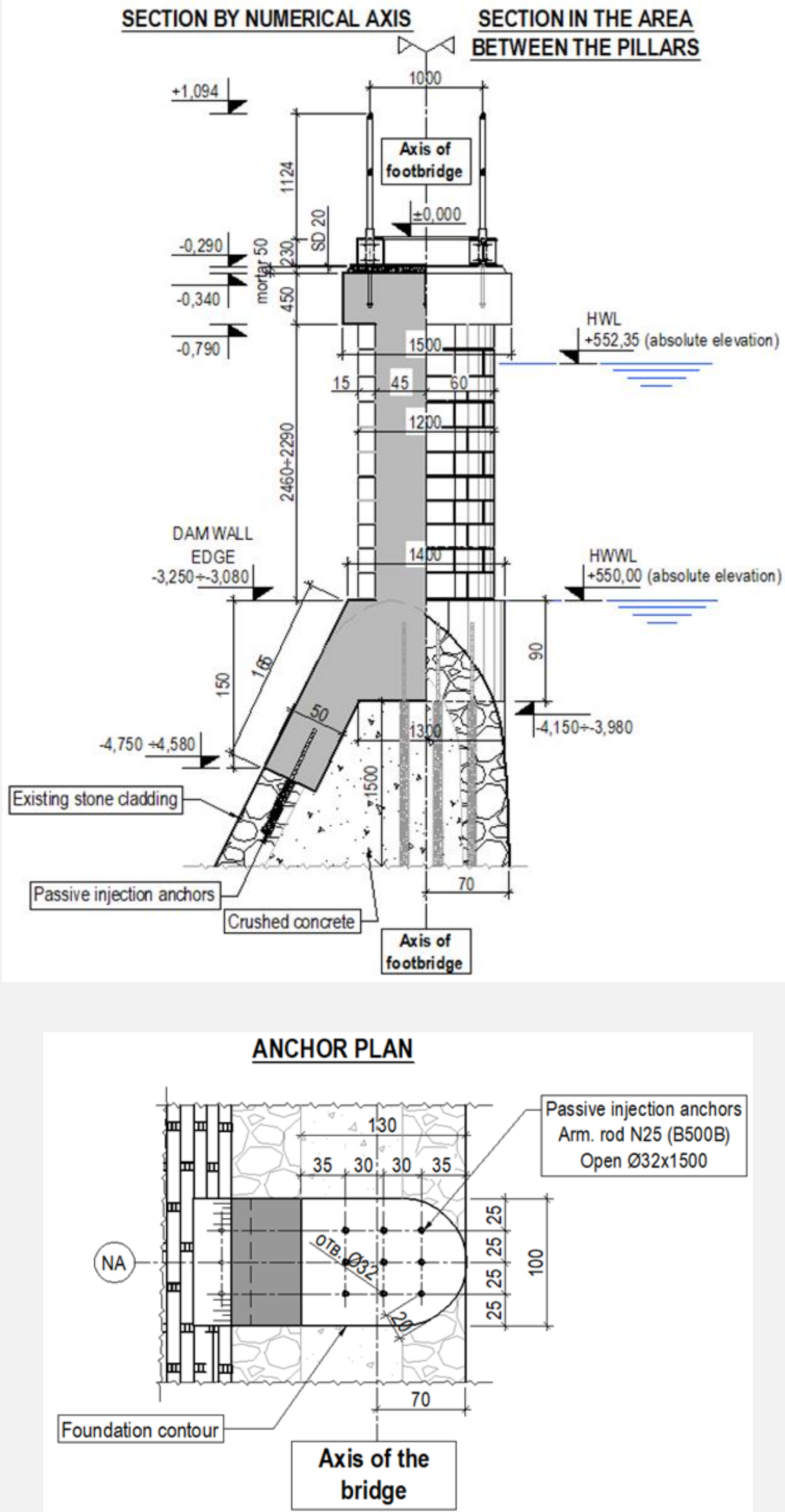

Figure 7. Project solution. Sections (up) and anchor plan (down) 
To prove the bearing capacity of the anchors in the foundation, a test is performed according to BDS EN 1537 ("Pool-out" test) on a test site, under conditions identical to the operational ones. Additionally, a test for acceptance is performed up to a test load $\mathrm{Pp}=50 \mathrm{kN}$ of at least $1 \mathrm{pc}$. foundation anchor.

\subsection{BEARING SYSTEM}

According to the original project - for a static scheme of the three fields of the existing part of the footbridge three single-opening fixed frames are adopted. In the design of the new superstructure a static scheme of individual articulated simply supported beam, is adapted, laterally fixed, fixed at one end and longitudinally free at the other end.

The connection with the existing and the new part is movable. The movement is carried out by means of friction surfaces of the lower flange of the main beams and supporting steel devices (SD1), pre-set as embedded parts in the crossbars of the columns. The movable connection is realized in deformation joints provided for this purpose, which also serve to absorb the temperature expansions of the elements. In addition to the joints, in the geometry of the node between two adjacent sections are provided bushings on the transverse end plates of the main beams, which compensate for the movement in the opposite direction - in case of temperature shrinkage of the structural elements. The space of the joints and bushings is filled with elastic polyurethane-based sealant.
UPPER STRUCTURE SECTION THROUGH STEEL PLATFORM

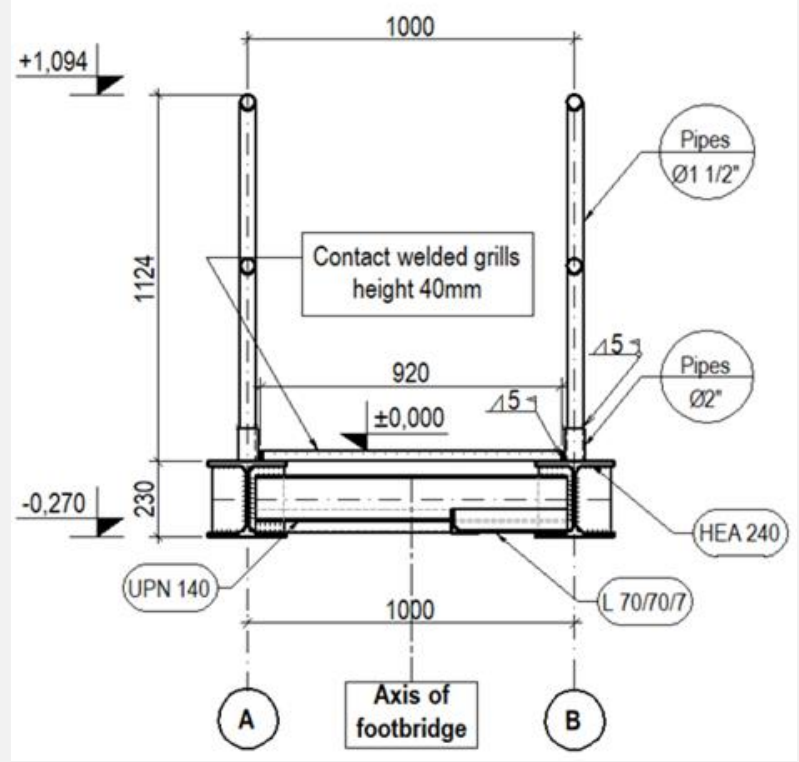

Figure 8. Upper structure. Section through steel platform

STATIC SCHEME

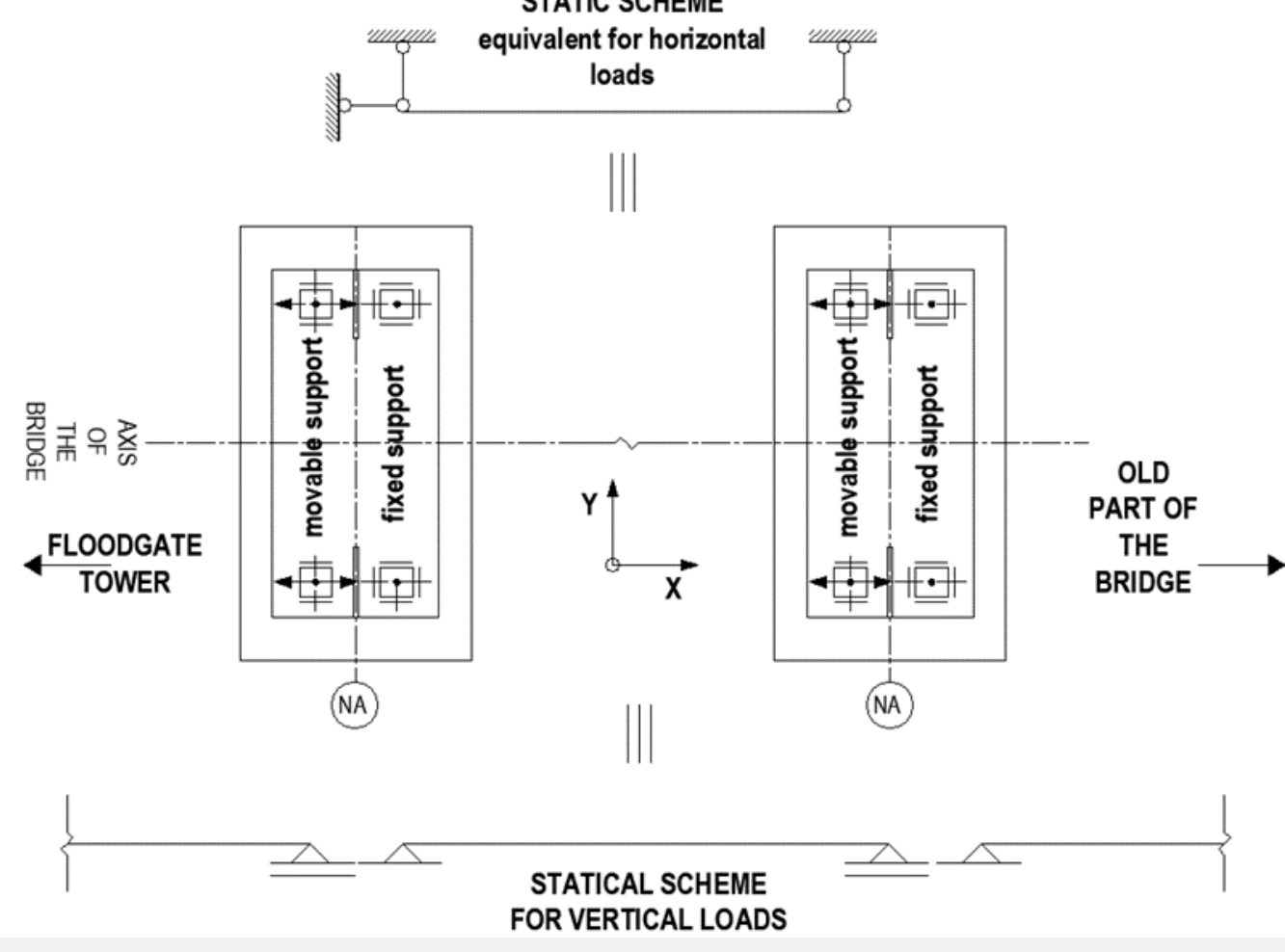

Figure 9. Bearing system. Static scheme for lateral and longitudinal movement 


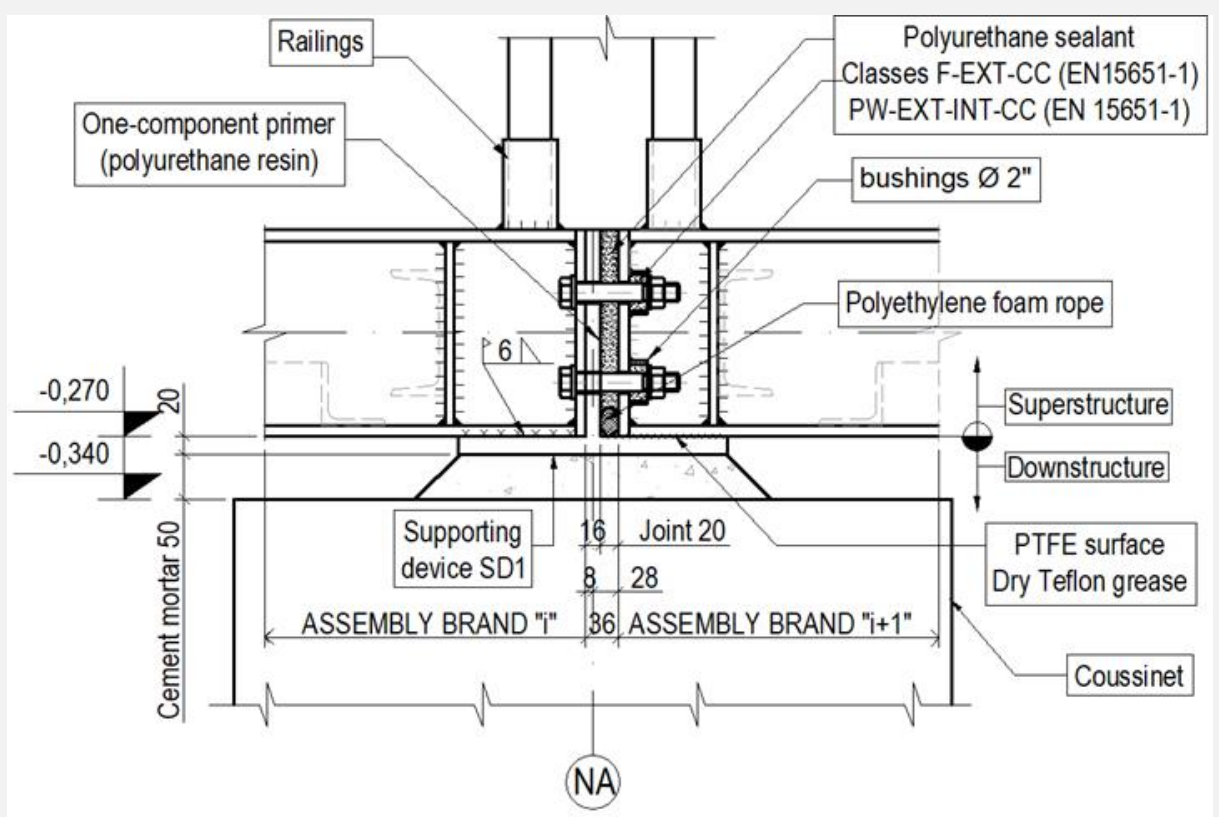

Figure 10. Detail of the node between the sections of the superstructure

\section{MATERIALS}

\subsection{Existing pillars}

The masonry pillars of the existing part of the footbridge are taken into account with a volume weight of $24 \mathrm{kN} / \mathrm{m}^{3}$ and a modulus of elasticity $\mathrm{E}=10000 \mathrm{MPa}$ [3].

\subsection{New foundations and pillars}

Ordinary concrete with a dense structure and dense aggregates will be used for the elements of the substructure. For the specific case, a risk of corrosion caused by carbonization (classes XC) and one caused by thawing and freezing (classes XF) is accepted. The waters of the Arda River are fresh, soft, slightly aggressive towards the Portland cement concrete. The selected compressive strength class is C30/37 (EN 2061).

- Density of reinforced concrete - $25 \mathrm{kN} / \mathrm{m3}$;

- Environmental impact class - XC4, XF3;

- Medium (cutting) modulus of elasticity $-E 0=33000$ $\mathrm{MPa}$.

\subsection{Steel structure}

The selected structural steel for sheet and linear products is non-alloy, hot rolled and weldable from class S235J2, according to BDS EN 10025-2. The full designation of steel grade according to EN10027-1 is S235J2 + AR.

\section{COMPUTATIONAL MODEL AND STRUCTURAL ANALYSIS METHOD}

A computational three-dimensional model with finite elements in the software environment of "SAP2000" v.14 has been generated. The pillars and the superstructure are modelled with beam "frame" elements, and "shell" elements defined for the pavement. The supports of the main beams are introduced eccentrically with respect to the axis of the columns and are connected to them by "link" elements with corresponding degrees of freedom to simulate the bearing system of the superstructure. For the stepping on the floodgate tower and on the stand at the left bank, movable and immovable supports were introduced, respectively. Permanent modal damping 5\% for the whole structure is accepted. 


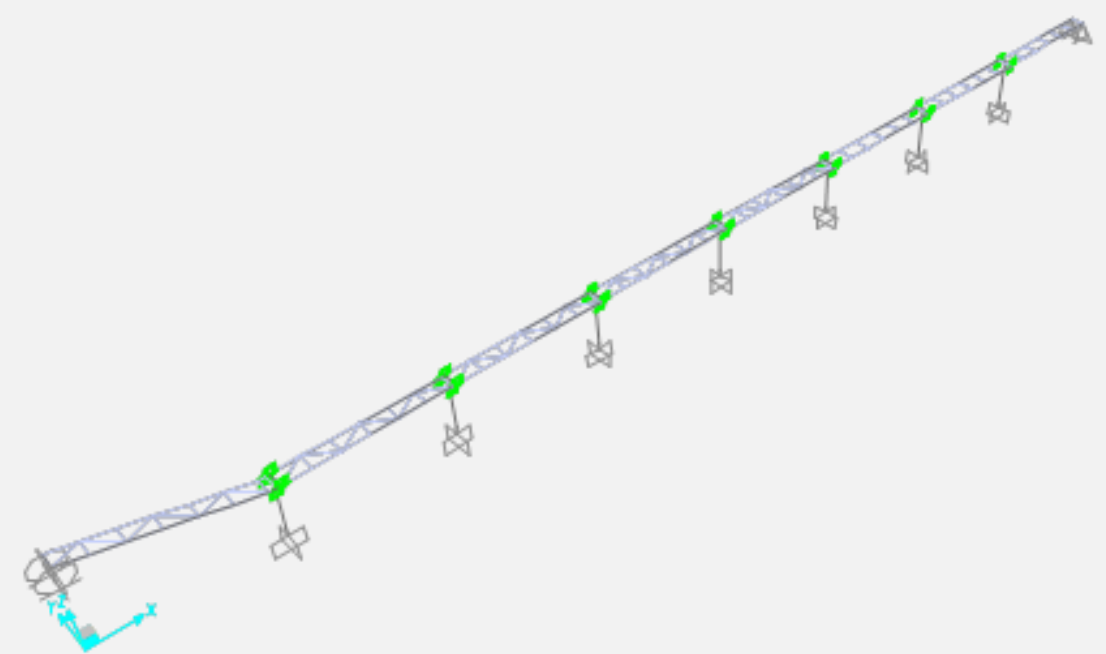

Figure 11. General view of the finite elements model

\section{LOADS AND IMPACTS}

The main points of the loads and impacts essential for the behaviour of the structure are cited.

\subsection{Variable loads}

\section{- Loads, caused by water}

The calculations are in accordance with the requirement of the Assignor to determine the hydrodynamic force when passing a high wave with a probability of exceedance $5 \%$, as well as checking with a high wave with a probability of exceedance $3 \%$. The data on the high wave values that were provided are as follows:

- High wave with probability $50 \% \ldots \ldots \ldots . . .477,5 \mathrm{~m}^{3} / \mathrm{s}$;

- High wave with probability $5 \% \ldots \ldots \ldots \ldots \ldots . . .1186 \mathrm{~m}^{3} / \mathrm{s}$;

- High wave with probability $1 \% \ldots \ldots \ldots \ldots . . .1630,2 \mathrm{~m}^{3} / \mathrm{s}$.

With the available data, a water quantity was calculated for the high wave with a probability of exceedance $3 \%$, by means of approximation with two probability distributions, selected as representative lognormal and Gumbel maxima I, and the higher obtained value was accepted as authoritative.

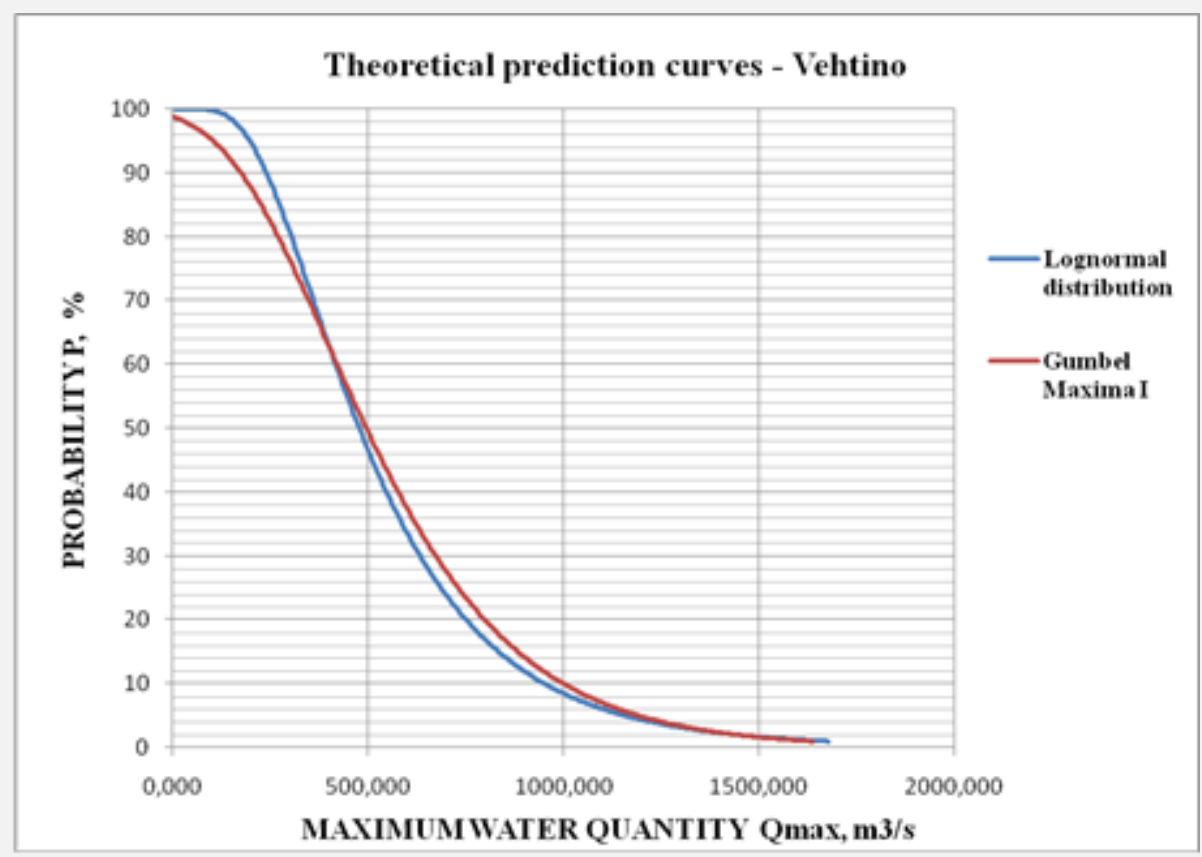

Figure 12. Theoretical prediction curves calculated from the data for the nearest hydrometric point - Vehtino 
- High wave with probability $3 \%$

$.1331,0 \mathrm{~m}^{3} / \mathrm{s}$

The appropriate water speed $\mathbf{v}_{0}$ is determined by the dependence:

$$
\begin{aligned}
& v_{0}=\frac{Q}{\left(H_{m p}+P\right) \cdot B_{m p} Q}=\varepsilon \cdot m \cdot B_{m p} \sqrt{2 g} \cdot H_{m p}^{3 / 2} \\
& \varepsilon=1-0,2 \frac{\xi_{y c r}+(n-1) \cdot \xi_{e r}}{B_{m p}} \cdot H_{m p} \text { - Lateral contraction }
\end{aligned}
$$
coefficient;

$\xi_{y c r}=1,0$ - Coefficient of resistance according to the shape of the side pillar;

$\xi_{\mathrm{er}}=0,45$. Resistance according to the shape of the intermediate pillar;

$\mathrm{n}=10$ - number of overflow openings;

$\mathrm{m}=0.48$. Coefficient of water quantity according to the shape of the dam wall.

The approach flow speed thus obtained determines the forces acting on the structure.

- Hydrodynamic force. According to BDS EN 19911-6: 2005 the magnitude of the total horizontal force from the main flow on a vertical surface is determined by the dependence:

$$
F_{\text {WG }}=\frac{1}{2} k \cdot \rho_{\text {Wa }} \cdot h \cdot b \cdot v_{\text {WG }}^{2}
$$

- Load from waste accumulation. According to BDS EN 1991-1-6: 2005 the magnitude of the total horizontal force from possible waste accumulation is determined by the dependence:

$F_{d e b}=k_{d e b} A_{d e b} v_{w a}^{2}$, where $k_{d e b}$ is a parameter for volume of waste. The recommended value according to BDS EN 1991 was accepted: $k_{\text {deb }}=666 \mathrm{~kg} / \mathrm{m}^{3}$

\subsection{SEISMIC IMPACT AND ANALYSIS}

To represent the seismic motion an elastic response spectrum Type 1 was used with identical components in the directions " $X$ " and " $Y$ " and parameters for the vertical component " $Z$ " - $\mathrm{avg}_{\mathrm{vg}} / \mathrm{a}_{\mathrm{g}}=0.85$, according to BDS EN 1998-1: NA.

The body of the dam wall is built on a rock base, for which a ground base type $A$ is accepted. The behaviour of the dam wall structure is considered to be an infinitely rigid body with equal accelerations along the height of the wall, because of which the columns of the bridge will receive the same accelerations as this at the base without signal amplification.

The value of the return period of repeatability for the requirement for non-destruction of the bridge $T_{\mathrm{NCR}}=475$ years is accepted (corresponding to probability of exceeding $\mathrm{P}_{\mathrm{NCR}}=0.19$ for design service life of 100 years) A.1 (2) BDS EN 1998-1: NA.

To reflect the seismic response of the bridge the reference procedure for linear dynamic analysis using a spectral method was adopted. For the lower structure at average of moderate seismicity of the site, the perceived behaviour is ductile limited $(q=1,5)$ so far as the deviation from the ideal elastic behaviour provides a certain dissipation of hysteresis energy without the need for plasticization in the range of the coefficient of behaviour $1,0<q<1,5$.

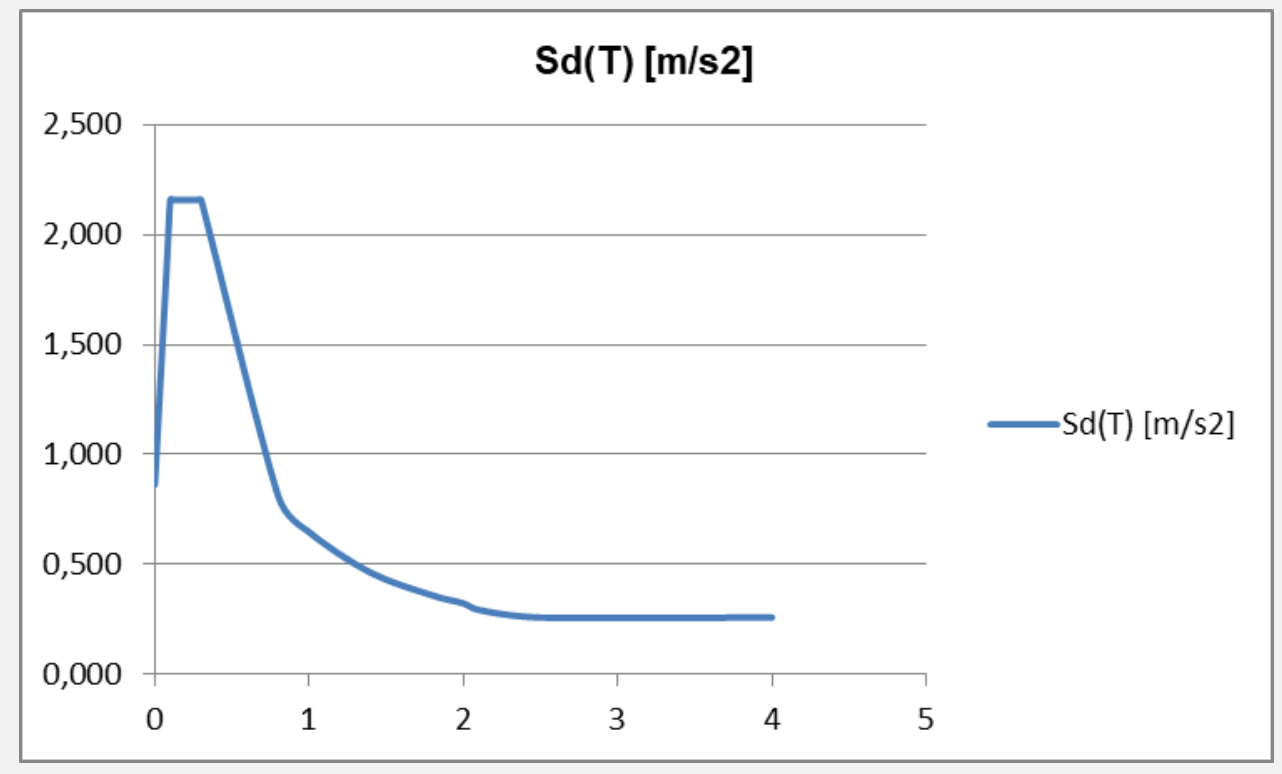

Figure 13. Computational response spectra for horizontal components at $q=1.5$, Ground type $A$, according to BDS EN 1998-1 / NA 


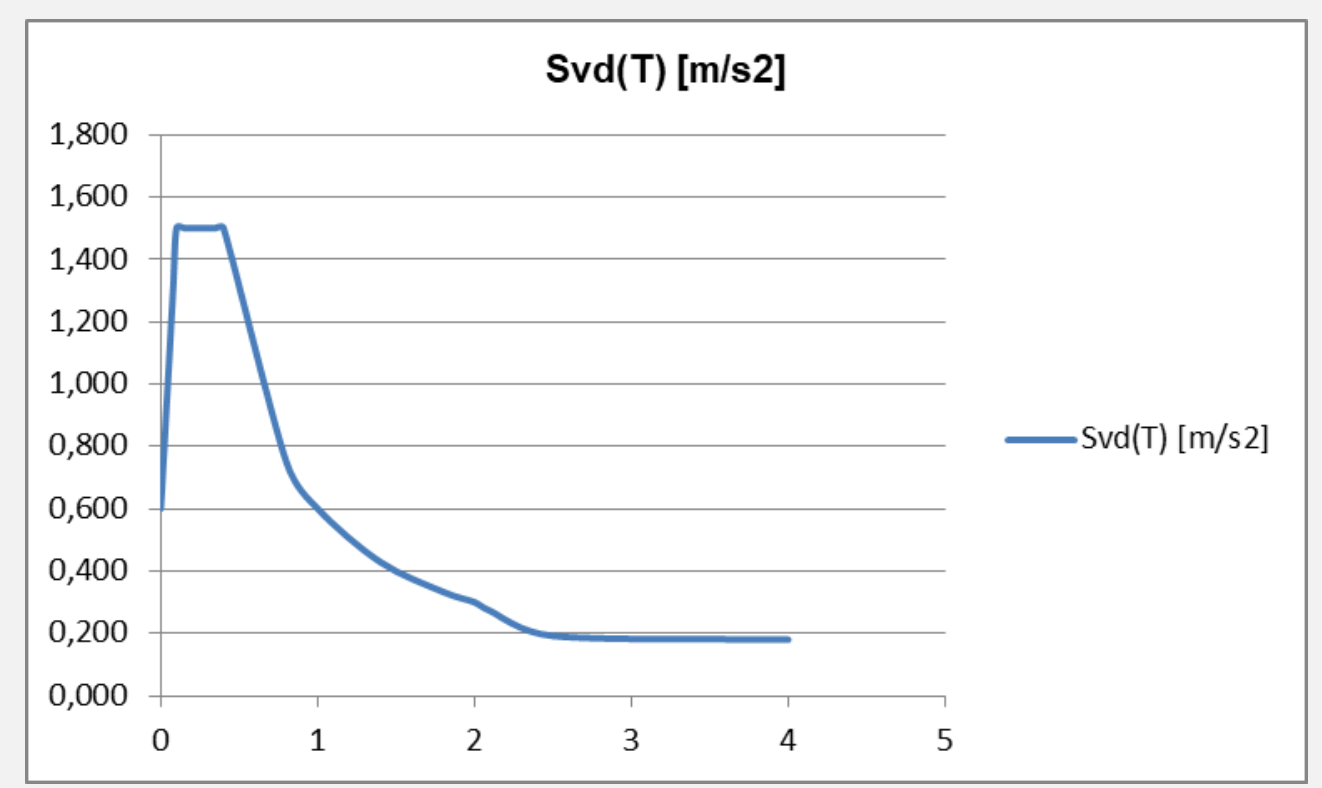

Figure 14. Computational response spectra for vertical components at $q=1.5$, Ground type $A$, according to BDS EN 1998-1 / NA

\subsection{Accidential impacts - strike from traffic on the river}

The impact is presented according to BDS EN 19911-7, by means of two mutually incompatible forces:

- Front force: $\quad F_{d x}=F_{d y n}=F_{\text {impact }} \varphi$

- Lateral force with one component acting perpendicular to the frontal force and one component of friction parallel to: $F_{d v}=0,5 . F_{d x}$,

$$
F_{R}=\mu \cdot F_{d v}=0,4,0,5 . F_{d:}
$$

The magnitude of the frontal impact force is determined by reference to a simplified formula (2-1) for determining the equivalent static force from a hard impact according to Annex C (BDS EN 1991-1-7: 2008):

$$
F_{\text {impact }}=V_{r} \sqrt{k \cdot m} \text {, where }
$$

" $k$ "- equivalent static stiffness of the impact object (the ratio between the force $F_{\text {impact }}$ and the total deformation). For inland waterway vessels, according to ISO DIS 10252 , a stiffness $k=5 \mathrm{MN} / \mathrm{m}$ ' is accepted.

To take into account the pulse nature of the load and the caused dynamic effects inside the structure, a dynamic gain coefficient has been adopted $\varphi_{\text {dvn }}=2,0$ , according to App. C (3) (BDS EN 1991-1-7: 2008).

\section{MODAL SPECTRAL ANALYSIS}

The constant impacts with their characteristic values and the quasi-constant values of the variable impacts with coefficient $\psi_{2,1}=0,2$ (according to item 4.1.2. EN 1998-2NA) are taken as masses.

The connected mass of water acting in the horizontal direction per unit length of the submerged column with dimensions $2 a_{x} / 2 a_{y}$ determined according to Annex $F$ of EN 1998-2 with the expression:

$$
m_{a}=k \rho \pi a_{y}^{2} \text {, where } \mathrm{k} \text { is a function of } \mathrm{a}_{\mathrm{x}} / \mathrm{a}_{\mathrm{y}} \text {. }
$$

The value of $\mathbf{m}_{\mathbf{a}}$ is entered as a linearly distributed load assigned along the height of the pillars up to the elevation highest water level (HWL) which provided by the Assignor.

The dynamic effect of the impact from pedestrians varies in the range of 0.5 to $3 \mathrm{~Hz}$ (according to item 5.7., EN 1991-2) and is outside the frequency response range of the bridge, whose first natural frequency is $\approx 5 \mathrm{~Hz}$. 

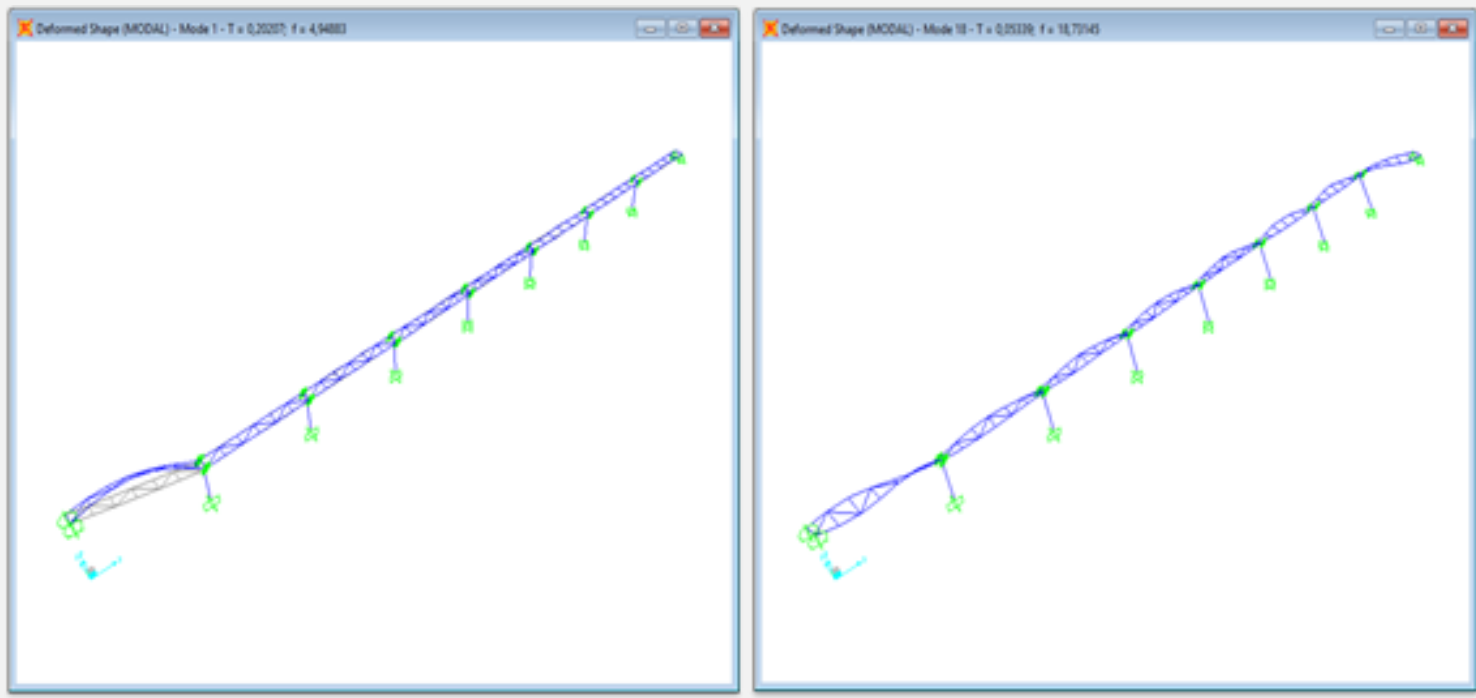

Figure 15. First modal form $(T 1=0.20 \mathrm{sec})$. First global translation form along the $Y$ axis $(T 18=0.05 \mathrm{sec}$

\section{METHOD STATEMENT}

The construction of the footbridge will be carried out from the dry slope of the dam wall and the flooding of the river must be taken into account during the annual period chosen for the construction. The peculiarities of the climate on the territory of Kardzhali district and in particular the area of the site are typical for the continental-Mediterranean climatic region: hot summer and mild winter, summer minimum and winter maximum rainfall, pronounced summer-autumn drought, episodic and non-permanent snow cover. In view of the climatic characteristics of the area and the distribution of run-off, the most suitable periods for rehabilitation are August November.

\subsection{Definition of individual stages}

The stage of temporary construction and mobilization of the construction site is commented.

1) Construction of a temporary access road incl. temporary ford for crossing the riverbed and construction of an embankment for technological berm in front of a dry slope

The temporary access road will be filled with ordinary gravel pavement at least $0.20 \mathrm{~m}$ thick, laid on a layer of crushed stone $0.25 \mathrm{~m}$ thick and compacted with a roller. The width of the lane in one-way traffic is assumed to be $4.0 \mathrm{~m}$. The transverse slope of the road should be in the range of $1.5-4.0 \%$. The construction of the ford begins with the laying of tubular reinforced concrete culverts across the direction of the flowing waters (deviation $15^{\circ}$ from the perpendicular is allowed) with diameter $\$ 1000$ and a number sufficient to conduct water quantities necessary for the normal functioning of ecosystems in the Arda riverbed. After laying the pipes, the embankment sections are formed with frontal barrier of the river waters, by means of intensive free embankment of unsorted crushed stone for "pressing" of the water flow to form a stone prism with a thickness of at least $0.40 \mathrm{~m}$ above the top of the gutter slope of the upper slope 1: 1.25 (1.0).

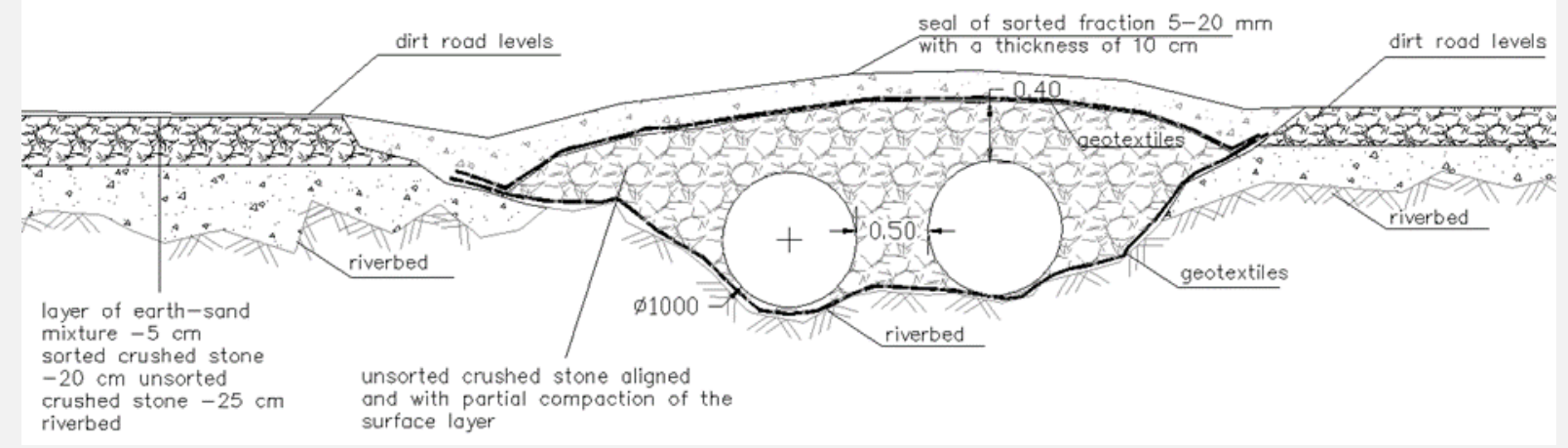

Figure 16. Typical longitudinal section of dirt road (ford) through the riverbed in a section above culverts 
2) Securing the site and installation / construction of scaffolding to the overflow wall, incl. delineation of storage areas

It is planned a self-supporting volumetric tubular metal scaffolding to be build in stages in four measures in order to provide work sites at the level of the crown of the wall. For a pillar in axis 3 , which is at the connection with the existing footbridge, the volumetric tubular scaffolding is not provided due to the very small free height to the crown, providing for the installation of a standard facade scaffolding (Hramar type) anchored in the rock massif and freely resting on the crown. The support towers are mounted above the rock massif by anchoring in it. A truss of universal tubular scaffolding elements develops between the support towers and the crown of the wall.

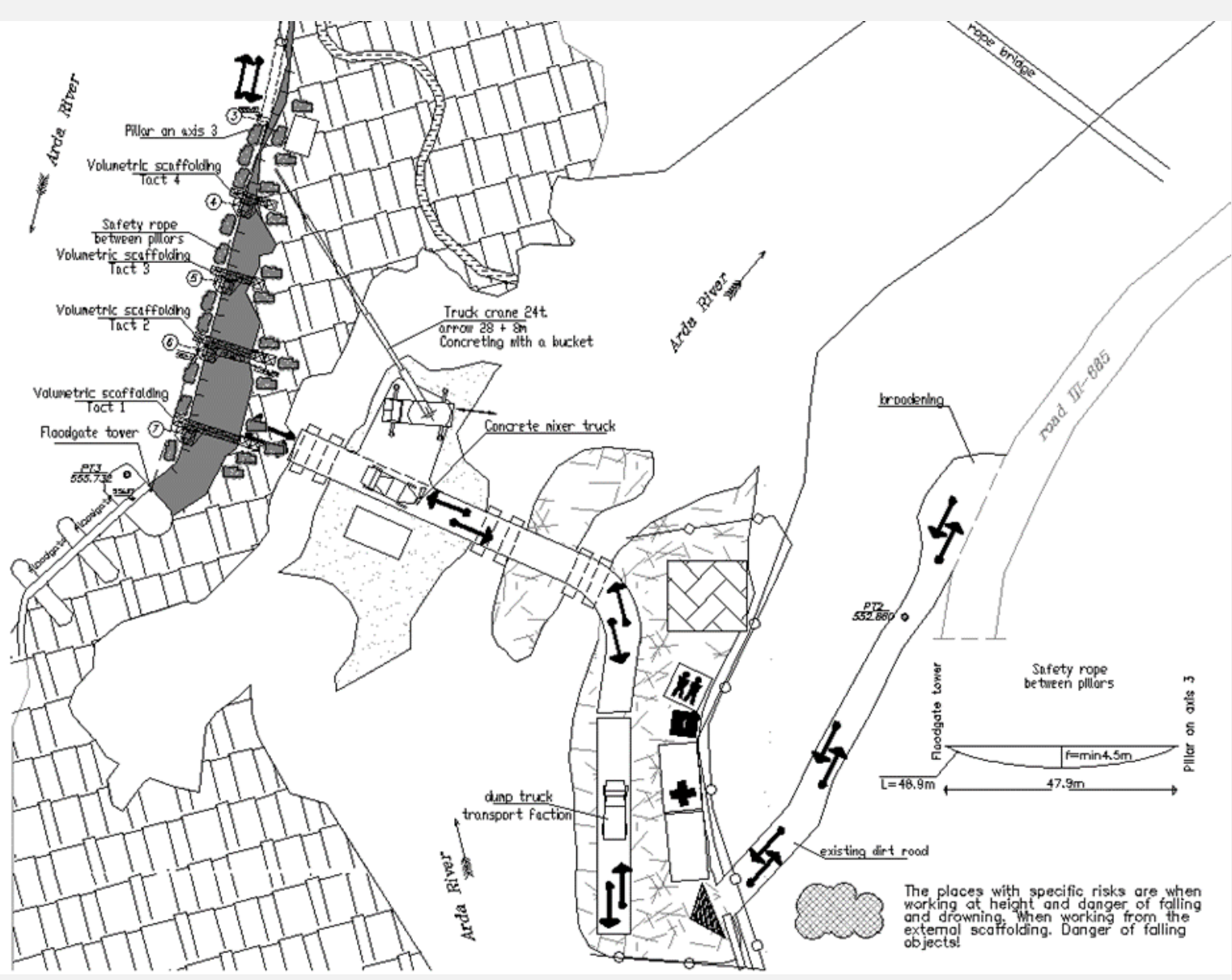

Figure 17. Construction situation plan

\section{CONCLUSIONS}

- With the measures adopted for reinforcement of the pillars and their anchoring in the body of the wall, their bearing capacity is significantly increased and they are able to absorb the design seismic impact for the site;

- With the increase of the wheelbase of the columns, in addition to the raster unity of the structure, an equal contribution of each of the columns in the control of the seismic energy is achieved, as the cutting forces will be commensurate along the entire length of the bridge;

- While preserving the material unity of the new and existing pillars, the goal is to evenly distribute the masses and stiffness in the plan of the facility. The stiffness of the new pillars is increased due to the reinforcement and this relieves the existing ones, as the pillar is the most loaded where the new and old part connect.

\section{REFERENCES}

[1] Eurocodes 1990-1998 and National Annexes for Bulgaria

[2] "Гидравлика", Энергоиздат Ленинград, 1982, Р.P Чугаев;

[3] „Masonry structures. Eurocode 6“, 2014, N. Barakova, T. Barakov;

[4] "Standards for design of hydraulic structures. Basics principles, BSA 11, 1985";

[5] "Standards for design of concrete and reinforced concrete structures of hydraulic structures" 24.02.1992. 


\section{SPECIFIC ASPECTS OF THE RETROFITTING DESIGN AND SEISMIC ASSESSMENT OF A HERITAGE PEDESTRIAN BRIDGE}

\section{Emil Yanev}

The purpose of this study is to establish a suitable structural system for the restoration of the destroyed part of the pedestrian bridge, which is a part of a hydrocomplex built along the Arda River (Bulgaria), and to improve the vulnerable details in the original structure, taking into account the seismic hazard on the site. The decision is also dictated by the choice of a construction method that does not interfere the Hydroelectric Power Plant (HPP) that is built along the river with the normal operation of which the subject is connected. The appropriate selection of materials and modelling of the overall behaviour of the old and new parts of the bridge are the basis of the optimal solution for interference with the structure and the possibility of extending its service life. It is also important to preserve the visual unity of the whole structural complex, thus preserving the original appearance and good construction practice from the time they have been built during the middle of the 20th century This design solution is part of an investment project of "Risk Engineering" Ltd..

Key words: Retrofitting of bridges, Maintenance of bridges, Seismic assessment

\section{SPECIFIČNI ASPEKTI PROJEKOTVANJA REHABILI- TACIJE I SEIZMIČKE PROCENE PEŠAČKOG MOSTA KAO GRADITELJSKO NASLEĐE}

\section{Emil YANEV}

Svrha ovog istraživanja je da uspostavi odgovarajući konstruktivni sistem za obnovu uništenog dela pešačkog mosta, koji je deo hidro-kompleksa izgrađenog duž reke Arde (Bugarska), i da poboljša povredljive detalje u originalnoj konstrukcijii, uzimajući u obzir seizmičku opasnost na lokalitetu. Odluka je takođe uslovljena/diktirana izborom načina gradnje koji ne ometa Hidroelektranu (HE) koja je izgrađena duž reke čiji je normalan rad povezan sa tim. Odgovarajući izbor materijala i modeliranje celokupnog ponašanja starih i novih delova mosta osnova su optimalnog rešenja vezano za ometanje i mogućnost produženja njenog životnog veka konstrukcije. Takođe je važno sačuvati vizuelno jedinstvo celog konstruktivnog sklopa, čime se zadržava prvobitni izgled i dobra građevinska praksa iz vremena kada su objekti građeni sredinom 20. veka. Ovo dizajnersko (projektno) rešenje je deo investicionog projekta „Risk Engineering“ Ltd.

Ključne reči: dogradnja mostova, održavanje mostova, seizmička procena 